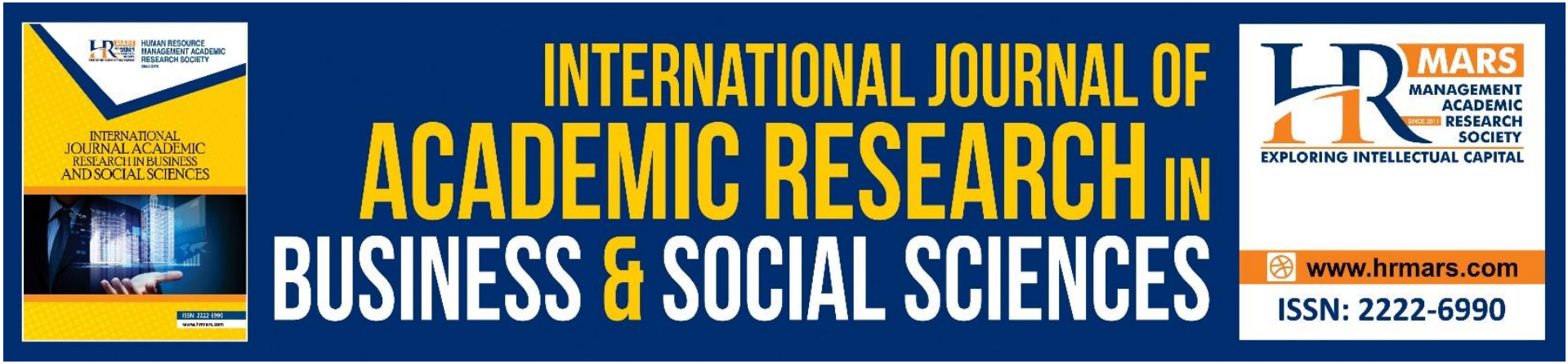

\title{
Revisit the Effect of Reverse Logistics Practices on Sustainability Performance
}

Yang Kaihan, Thoo Ai Chin

To Link this Article: http://dx.doi.org/10.6007/IJARBSS/v11-i11/11424

DOI:10.6007/IJARBSS/v11-i11/11424

Received: 03 September 2021, Revised: 07 October 2021, Accepted: 27 October 2021

Published Online: 14 November 2021

In-Text Citation: (Kaihan \& Chin, 2021)

To Cite this Article: Kaihan, Y., \& Chin, T. A. (2021). Revisit the Effect of Reverse Logistics Practices on Sustainability Performance. International Journal of Academic Research in Business and Social Sciences, 11(11), $2093-2110$.

Copyright: @ 2021 The Author(s)

Published by Human Resource Management Academic Research Society (www.hrmars.com)

This article is published under the Creative Commons Attribution (CC BY 4.0) license. Anyone may reproduce, distribute, translate and create derivative works of this article (for both commercial and non0-commercial purposes), subject to full attribution to the original publication and authors. The full terms of this license may be seen at: http://creativecommons.org/licences/by/4.0/legalcode

Vol. 11, No. 11, 2021, Pg. $2093-2110$

Full Terms \& Conditions of access and use can be found at http://hrmars.com/index.php/pages/detail/publication-ethics 


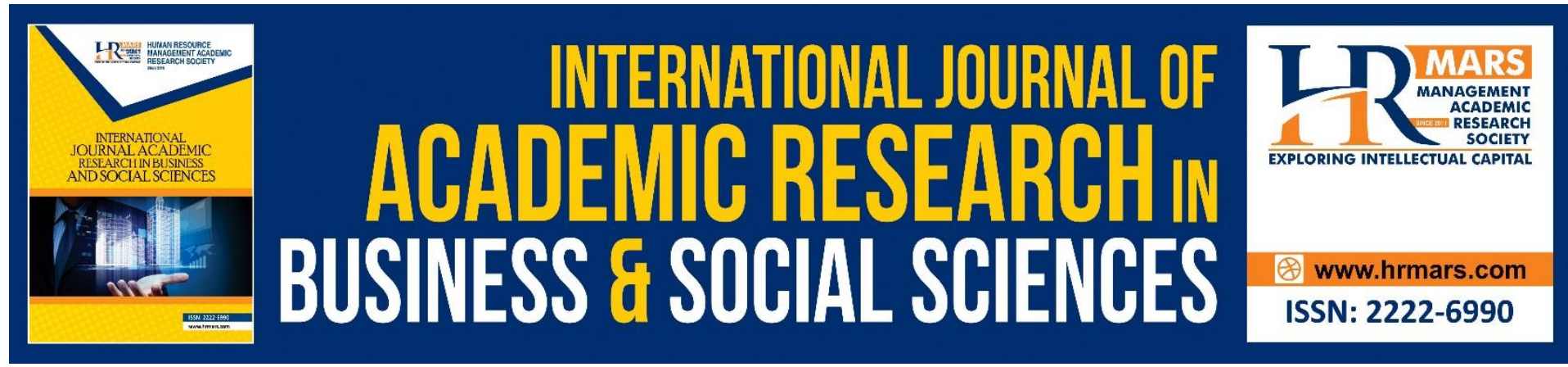

\title{
Revisit the Effect of Reverse Logistics Practices on Sustainability Performance
}

\author{
Yang Kaihan, Thoo Ai Chin \\ Azman Hashim International Business School, Universiti Teknologi Malaysia, 81310 Skudai, \\ Malaysia. \\ Email: yangkaihan@graduate.utm.my
}

\begin{abstract}
The increasing concern about environmental and energy conservation leads industries to serve the sustainability development as one of important issues. Reverse logistics can manage product returns effectively and play an important role in achieving the sustainability goals of any organization. As a result, many companies have been paying close attention to reverse logistics and made it a strategic decision. Despite the fact that reverse logistics can significantly increase the organization's sustainability performance, there has been little research into the relationship between reverse logistics and sustainability performance. Thus far, few researchers have examined the impact of reverse logistics disposition decisions on the triple bottom line (TBL), which includes economic, environmental, and social performance. Thus, this paper aims to review the impact of reverse logistics on sustainable performance and examine which option of the disposition decision is more suitable for the sustainable performance. Also, content analysis was used to analyse the selected papers on reverse logistics and sustainability performance. Ultimately, this study concludes that the impact of reverse logistics on social aspect have been largely neglected. Also, this study suggests that future researchers should concentrate on the empirical studies on how each disposition option of reverse logistics may influence the sustainability performance.
\end{abstract}

Keywords: Sustainability, Sustainable Performance, Triple Bottom Line, Reverse Logistics, Disposition Options

\section{Introduction}

According to the World Meteorological Organization, 2015-2019 was the warmest period on record, with a 0.2 percent rise in global climate change over 2011-2015. (WMO, 2019). One of the causes for this shift was a $20 \%$ increase in global carbon emissions, which has reached 410 parts per million of carbon emissions at the end of 2019. In addition, 831 climate-related extreme events caused a total of US\$166 billion in global economic losses and a new high of $55.3 \mathrm{Gt}$ of $\mathrm{CO}_{2}$ equivalent emissions in 2018 (Zhang et al., 2020). As a result of the growing socio-environmental problem, involving climate change, pollution, and multiple health concerns caused by pollutions, all countries are now concerned about sustainable development (Khan et al., 2019). All the United Nation member nations adopted the Sustainable Development Goals (SDGs) in 2015 to eradicate poverty, safeguard the 
environment, and ensure prosperity by 2030 . In this period of sustainable development, all companies are suggested to increase awareness to pursuit sustainability development goals concerned with social well-being, economic development, and environmental protection (Tsalis et al., 2020). Also, numerous organizations have included sustainability into their missions, and they have made ongoing attempts to fulfil their commitment to sustainability (Digalwar et al., 2020).

The term sustainability refers to a generation's ability to meet their own needs without jeopardizing the needs of future generations. The existence of three critical elements (social, environmental, and economic) for product manufacturing can be defined as the fundamental concept of sustainability. Adopting sustainable principles can help businesses make more surplus and stay in business for the long term. Sustainability development has been one of critical issues. On a company level, reverse logistics ( $R L)$ makes the most contribution to better global sustainability. Well-managed RL initiatives can attain sustainability and generate a competitive advantage through boosting profits, lowering expenses, and enhancing customer happiness.

Furthermore, reverse logistics enables industries to recapture value that would otherwise be lost. For example, a remanufactured engine can significantly reduce emissions by $565 \mathrm{~kg} \mathrm{CO} 2$, $6.09 \mathrm{~kg} \mathrm{CO}$, and $3.98 \mathrm{~kg} \mathrm{SO} 2$ compared to a new engine (i.e., no remanufactured products) (Kasman et al., 2015; Zhang and Chen, 2015). Moreover, the retail price of a remanufactured product is often $50 \%$ to $70 \%$ less than that of a new one (Hazen et al., 2017). In terms of job creation, the social viewpoint must also be taken into account when determining the need for reuse, recovery, and recycling operations (reverse logistics activities). However, the global unemployment rate was $5 \%$, which can be reduced in the future due to an increase in the number of jobs generated internationally (Kühn, 2019). This demonstrates that increasing the usage of reuse, recycling, and recovery operations will promote resource conservation and result in more job creation and a lower unemployment rate around the world.

However, much of the previous research has concentrated on the economic and environmental advantages of RL. There is a paucity of research examining the relationship between RL and sustainability, as well as analyzing how RL disposition alternatives, involving recycle, reuse, repair, remanufacturing, can improve sustainability performance by integrating the three sustainability pillars (Banihashemi et al.,2019). To fill up the gaps in the literature, this study examines the literature on RL and sustainability performance and assesses the performance of the RL disposition options in three dimensions of sustainability: environmental, economic, and social.

\section{Concepts and Definitions \\ Reverse Logistics}

The reverse logistics concept has received increased attention because of multiple factors, including competition among organizations, environmental interference, social marketing, and economic elements (Kabir, 2013; Alkahtani et al., 2021). Reverse logistics can reroute flows from the point of consumption back to the point of origin to recover value or dispose of waste properly. Reverse logistics refers to the flow of information and materials backwards for reuse, recondition and recycling valuable parts that can be resold in the market after undergoing transformation into new products (Anne et al., 2016). Nevertheless, from a comprehensive viewpoint, reverse logistics is deemed as a management process, including the cost-effective and efficient inputs flow, partially completed products, end products, and the related information from the end-user to the organization that initially sold the products 
to capture the value and for environmental protection through appropriate disposal (Murphy, 2012). According to this review, the study definition considers the sustainable development aspect. Thus, in this study, reverse logistics mainly denote returning products from the consumption point to the origin location. The objective of reverse logistics does not only pursuit economic and environmental benefits but also pursuit social performance.

\section{Sustainability Performance}

The term sustainability has been coined as the present generation's ability to fulfil their necessities without bargaining with the future generations' needs. The vital sustainability concept can be defined as the presence of three crucial elements (social, environmental, and economic) in manufacturing products (Beske et al., 2014). Firms and businesses do not focus only on the economic sustainability aspect. However, they strive for environmental and social performances as these two indicators have gained impetus despite the complications in measuring the performance. Thus, many organizations shift to sustainable results as stakeholders emphasize society and the environment (Kang, 2015).

Various literature (e.g., Fahimnia et al., 2015; Tajbakhsh and Hassini, 2015; Mariadoss et al., 2016) studied the significant implications where environmental and social sustainable supply chain strategies adoption positively impact sustainable economic performance. Carter and Rogers (2008) stated that organisations emphasising the three bottom lines could attain better economic performance than organisations focusing on either one or two of the components (Mirkouei, 2017; Moktadir, 2018). Higher economic gains encourage organisations to adopt better social responsibility (Mota, 2015). Organisations with robust economic strength can splurge additional money on treating pollution, offer advantages to the society and enhance the employees' wellbeing (Cao and Zhang, 2011; Li et al., 2014).

This research's sustainability performance mainly refers to firms need to operate manufacturing activities by considering all three basic dimensions (economic, social and environmental performance). Subsequently, the firms can minimise the cost of returns, improve customers' satisfaction, reduce community complaints, highlight the design of recyclable pallets and packaging, decrease unwarranted deliveries, and utilise green substances on product design to minimise environmental influences. Thus, sustainability performance can be assessed according to the economic, society, and environmental impact (Chopra and Meindl, 2016).

\section{Methodology}

The content analysis method was selected to conduct the literature evaluation in this study since it is ideal for observational research and can systematically assess the symbolic content of all sorts of written records. The content analysis approach also aids researchers in identifying and analysing literature to shape various categories, which can aid in the development of a new research domain.

This research exclusively includes papers published in English-language academic journals and conference articles between 2010 and 2021. As a result, papers written in other languages are no longer accepted. Scopus, Web of Science, Emerald, and Google Scholar databases were used to compile the data for this study. The keywords "reverse logistics," "sustainability," "sustainability performance," and "sustainable development" were used to find articles. Table 1 lists all the review process. A total of 309 papers were collected after being checked for substance and relevance, and 49 papers were chosen and examined. 
Table 1. Review process

\begin{tabular}{|c|c|c|}
\hline Steps & Process & $\begin{array}{l}\text { Systematization } \\
\text { of data }\end{array}$ \\
\hline $\begin{array}{l}\text { Define } \\
\text { Research } \\
\text { Problem }\end{array}$ & $\begin{array}{l}\text { Define research themes of reverse logistics and } \\
\text { sustainability performance. }\end{array}$ & \\
\hline $\begin{array}{l}\text { Article } \\
\text { searching }\end{array}$ & $\begin{array}{l}\text { Searching articles in Scopus, Web of Science, Emerald } \\
\text { and Google Scholar databases with keywords. }\end{array}$ & 309 \\
\hline Exclusion & $\begin{array}{l}\text { To capture recent developments in the topic, the search } \\
\text { includes both journal and peer-reviewed conference } \\
\text { publications. }\end{array}$ & 307 \\
\hline Limited & $\begin{array}{l}\text { Following several rounds of refining, it was determined } \\
\text { to limit the research fields (known as "subject area" in } \\
\text { databases) to environmental science, engineering, } \\
\text { business, economic, social sciences, and decision } \\
\text { sciences. }\end{array}$ & 255 \\
\hline Inclusion & $\begin{array}{l}\text { Search String with Article Inclusion Criteria: } \\
\text { - Full-text articles can access. } \\
\text { - The paper should contain the research subject, } \\
\text { which are "reverse logistics" or "sustainability } \\
\text { performance". } \\
\text { - The objective of articles should match the paper. }\end{array}$ & 59 \\
\hline $\begin{array}{l}\text { Articles } \\
\text { identification }\end{array}$ & Comprehensive investigation of research articles. & 49 \\
\hline
\end{tabular}

\section{Results and Discussion}

\section{Classification the Journals}

The title, abstract, and objective of all the publications were assessed using the inclusion criteria, resulting in the rejection of 196 papers ( 77 per cent of the total). The introduction and conclusion of the chosen 59 papers ( 23 per cent) were read, resulting in 49 papers being selected. In the last ten years, the selected publications have appeared in 29 different journals. The distribution of publications by the journal is depicted in Figure 1. (Bule bars). The Journal of Cleaner Production produced the most papers (7 publications), which can be explained by the journal's strong connection to cleaner production, environmental issues, and sustainability concerns. Furthermore, the International Journal of Production Research and Benchmarking: An International Journal and the International Journal of Production Research and Benchmarking: An International Journal each presented four and three publications, respectively, which could be attributed to the primary focus of the journals as mentioned above and their relationship to the current question in focus. The remaining articles come from several periodicals covering a wide range of topics, including mechanical and sustainable design, renewable energy, production economics, and clean technology. Finally, the 49 publications were thoroughly investigated, and 24 were selected to examine sustainability performance metrics. 


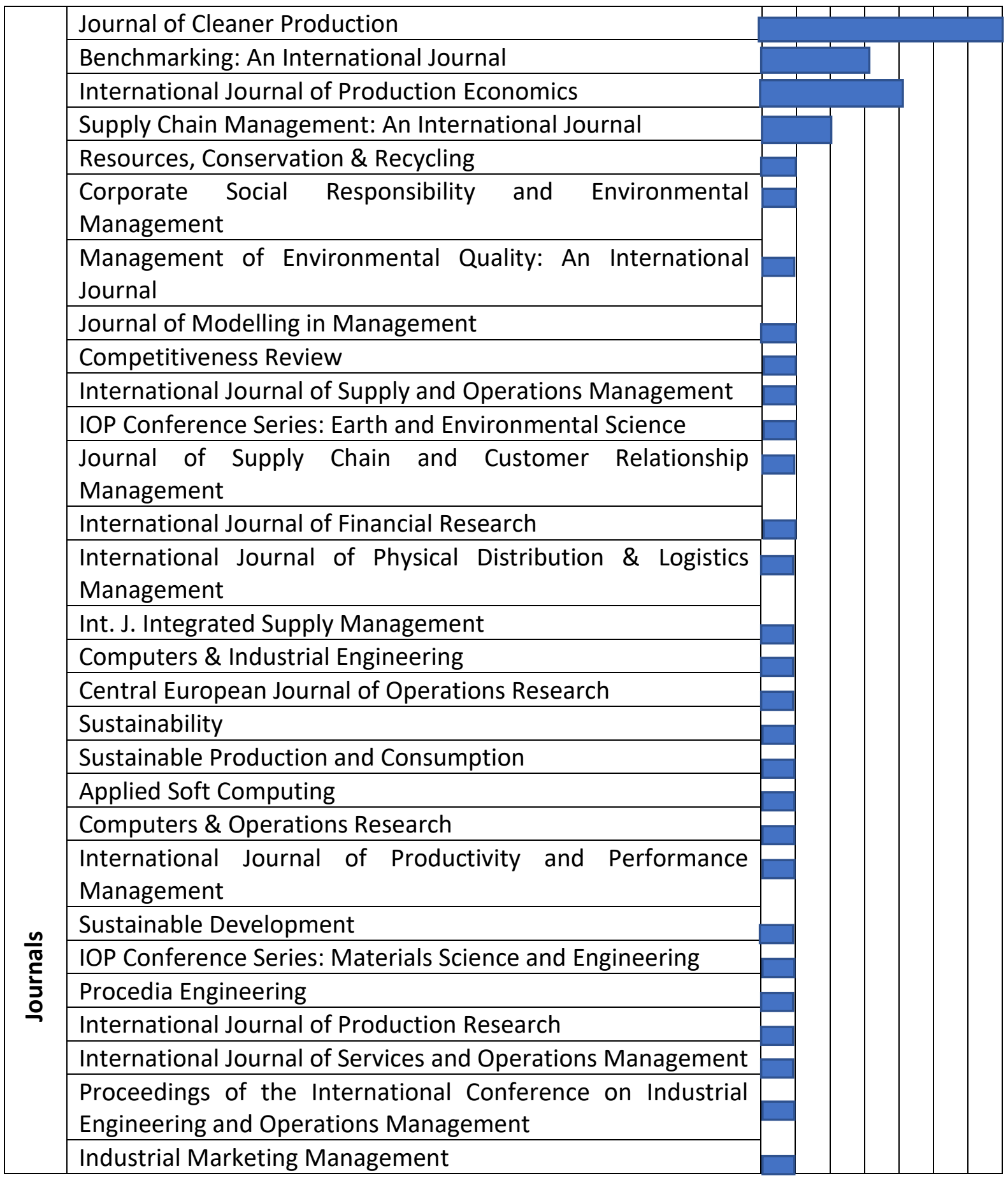

Fig. 1. Journal distribution of selected publications (in blue)

\section{Analysis of Performance Indicator Classification According to TBL Dimensions Economic Performance}

Economic performance is an integrated dimension in sustainability performance (Ahmad et al., 2019), indicating that corporates pursue long-term profit development (Delai and Takahashi, 2011). The long-term economic value primarily suggests that firms should focus on the share value, profit growth, sales growth and market competitiveness while maintaining social and environmental responsibilities (Ahi and Searcy, 2013; Luthra et al., 2019). The companies should reduce the cost to reap maximum profits for economic sustainability by optimising resources and raw materials utilisation (Mandal, 2013). 
Profit and cost are the common economic indicators (Ahmad, 2018). The economic indicators of the past decade were reviewed (Refer to Figure 2). The indicators are categorised under two aspects: profits and cost. The first indicator, namely 'reduce the cost', focuses on reducing the purchased inputs cost, energy consumption cost and operational expenses, such as waste management. The second indicator, 'profitability', emphasises sales revenue and profits. Comparatively, the focus of economic evaluation and assessment is more on profit analysis than cost analysis.

Most studies include profit-based indicators. Nevertheless, 12 papers evaluated the costrelated indicators. For example, Faisal (2012); Sangwan et al (2019); Narimissa et al (2020) and Neri et al (2021) have excluded the cost dimension. These studies considered profits maximisation as the goal of supply chain optimisation and scheduling. Alternatively, many studies considered the cost of waste management, resources (e.g., packing and raw materials) and energy as economic performance indicators (Uysal, 2012; Chardine-Baumann, 2014; Gopal and Thakkar, 2015; Baba et al., 2019). These studies emphasised that economic sustainability's goal is the logistic cost reduction or profit maximisation in various supply chain actions across the product's lifecycle stages.

This study describes economic performance as the cost reduction effort by managing manufacturing-related activities to incur a lower cost and generate profits or attain higher revenue growth via increased sales and returns in investments. Supply chains are valuable resources for organisations that support achieving cost reduction and producing high-quality products on time to fulfil market demands and generate profits. Therefore, manufacturers that suit the organisations' objectives must be selected and developed to achieve better economic performance.

\section{Environmental Performance}

Environmental performance indicates that companies minimise environmental damage by reducing pollution, recycling and reusing waste products, and reducing excessive use of resources (Touboulic and Waler, 2015). Figure 2 displays all the environmental indicators. These indicators are categorised into three categories, including environmental input, environmental output, and product stewardship. The analysis demonstrated that the environmental assessment indicators were not engaged equivalently in the previous studies that were reviewed. For example, environmental output was identified to be frequently investigated than product stewardship. The focus on environmental output could have resulted from broader global consideration and emphasis on air and solid emissions (Liu et al., 2016).

Besides, the environmental output is highlighted frequently because of scenarios where solid waste from the manufacturing industry causes the landfills to pollute the air, soil and groundwater and causes grave harm to human health (Varsei et al., 2014; Verdecho et al., 2020). Figure 2 demonstrates that environmental input is based on numerous indicators, such as resource, energy, materials, and others. Thus, the efficiency of environmental input has proven to save costs and energy in supply chain activities within the manufacturing industry (Tajbakhsh and Hassini 2015; Sopadang et al., 2017).

This study evaluated environment performance from the perspective of prevention and reduction efforts. Reduction efforts involve reducing emission, raw materials input, and utility usage, whereas prevention efforts include using alternate environment-friendly resources, production methods and energy sources for environment preservation activities implemented by an organisation (Gomes et al., 2014; Eikelenboom et al., 2019). 
This study evaluated environment performance from the perspective of prevention and reduction efforts. Reduction efforts involve reducing emission, raw materials input, and utility usage, whereas prevention efforts include using alternate environment-friendly resources, production methods and energy sources for environment preservation activities implemented by an organisation (Eikelenboom et al., 2019).

\section{Social Performance}

Social performance is among the sustainability dimensions that should not be overlooked (Shibin, 2017). Ethics and social values are the inevitable dimensions of sustainability performance in organisations (Gunasekaran and Spalanzani, 2012). Social performance denotes the dynamic values of undesirable and social concepts, and the ways personal goals are incorporated to serve social objectives (Akotia, 2014). Nevertheless, products should meet the demands and needs of the population to attain social sustainability (Mandal, 2013). The social indicators are classified by stakeholders or affected parties, including customers, employees, and the community (Qureshi et al., 2017). Figure 2 shows the analysis and review of social indicators in the past decade. According to Sopadang et al (2017) and Ahmad et al. (2019), the indicators are first categorised according to the stakeholders, including employees, community, and customers. The employee category was highlighted frequently in all the reviewed studies (Varsei et al., 2014; Stindt, 2017). In Sopadang et al (2017) study, the customers' satisfaction is deemed the main output of social performance.

Nevertheless, the community category was comparatively less highlighted from the perspective of sustainability assessment. The total sustainability score might assist in identifying key issues of contention among supply chain stakeholders (employees, community, and customers). In contrast, the overall sustainability score in the community (75\%) indicated that the community is imperative in social sustainability (Sopadang et al., 2017).

The primary interests in the employee category focus on fundamental labour rights that are based on indicators, such as wage or salary (Hassini et al., 2012; Reefke and Trocchi, 2013; Gopal and Thakkar, 2015; Izadikhah and Saen, 2018), safe working conditions (Varsei et al., 2014; Stindt, 2017; Narimissa et al., 2020), training (Hassini et al., 2012; Chardine-Baumann, 2014; Gopal and Thakkar, 2015; Tajbakhsh and Hassini, 2015; Baba et al., 2019), and development (Ahi and Searcy, 2015; Sopadang, 2017; Narimissa et al., 2020). Nonetheless, other indicators of the employee category, such as labour satisfaction (Neri et al., 2021), was less employed in the reviewed studies. Hassini et al (2012); Ahi and Searcy (2015), and Sopadang (2017) demonstrated that the identified key indicators in the social dimension of performance are customer and employee satisfaction.

Therefore, social performance measurement in this study used the organisations activities concerning stakeholders' health and safety, equal treatment and satisfaction. Unacceptable working conditions in industry include child labour, hazardous chemicals usage, safety issues in factories, forced labour, and low wages. The unacceptable working conditions are among the social concerns (Köksal et al., 2017) related to the social risks in the supply chain that a company could face. 


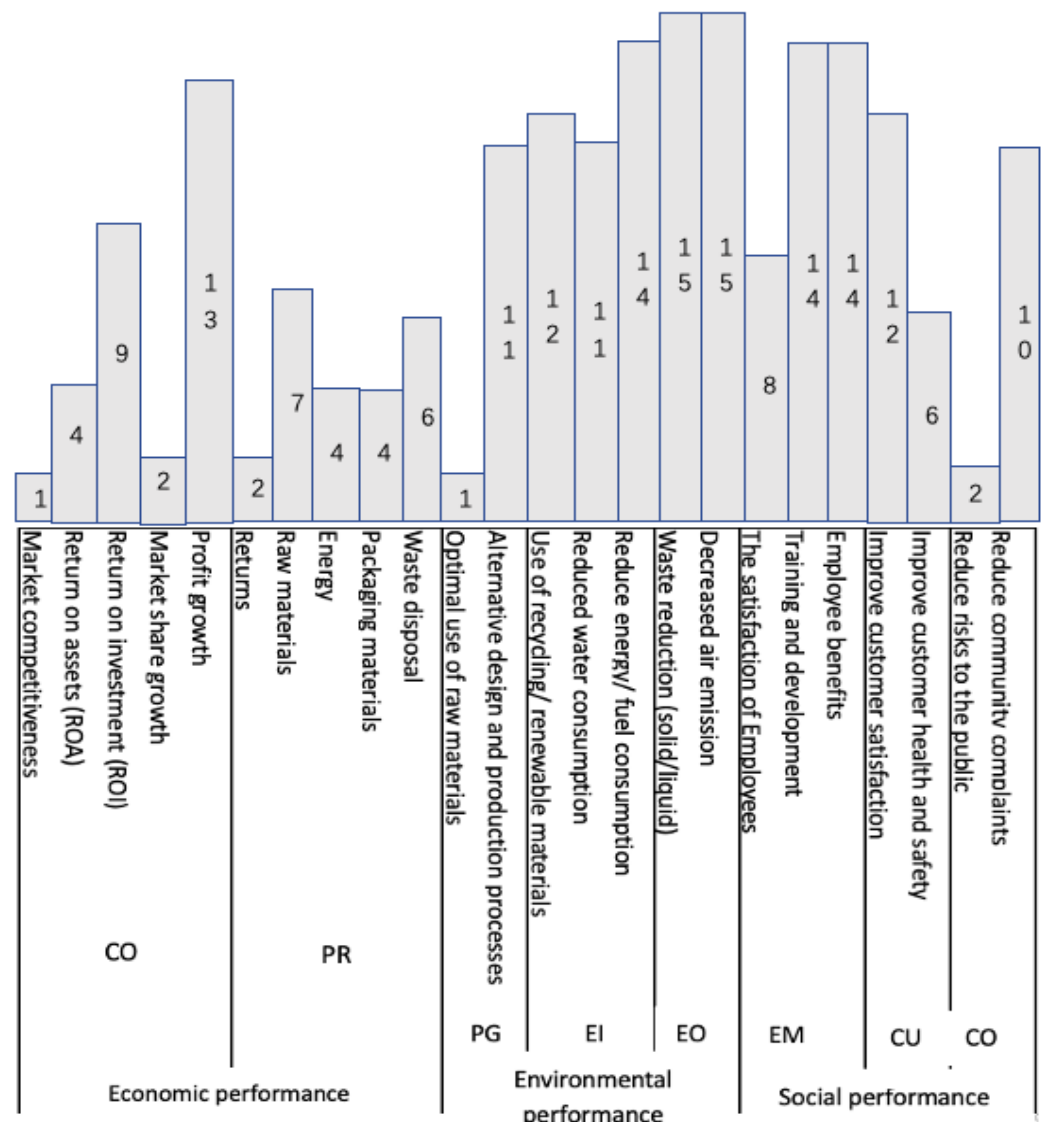

Fig. 2. Total number of performance indicators capturing sustainability performance dimensions and corresponding aspects, where grey bars highlight aspects, covered by indicators most frequently proposed in the literature.

[Note=Co: Cost; PR: profit; PG: Product Stewardship; El: environmental Input; EO: Environmental Output; EM: Employee; CU: Customer; CO: Community]

\section{Reverse Logistics Dimensional Framework}

Based on the sustainability concept, waste prevention via reverse logistics practice has recently drawn scholars' attention (Plaza-Úbeda et al., 2020). Reverse logistics practice is defined as recovery of the goods whose lifetime fails to end. Similarly, reverse logistics can also be considered to salvage goods that are not beneficial for users (Afum, 2019). Organisations implement various reverse logistics methods. Several researchers (e.g., Eshikhati, 2014; Ndung'u and Moronge, 2017; Agrawal and Singh, 2019) recognised remanufacture, reuse, repair, recycle, and disposal as the generally implemented reverse logistics methods.

Figure 3 shows the typical reverse logistics practices that include recycling, reuse, remanufacture, repair and disposal (Agrawal and Singh, 2019), updated from Alkahtani et al. (2021). Reverse logistics has been recognized as an important part of the sustainable supply chain management (SSCM) strategy (Afum, 2019). Furthermore, recalling customers' used products to reuse, remanufacture, recycle, repair, and disposal can enhance the value of returned items while lowering the overall cost (Sharma et al., 2011). Campos et al. (2017) denoted that salvaging used products is more economical than direct disposal. Thus, deciding dispositions appropriately, including reuse, repair, remanufacture or recycling, is necessary for organisations to recapture value (Basnihashemi et al., 2019). 


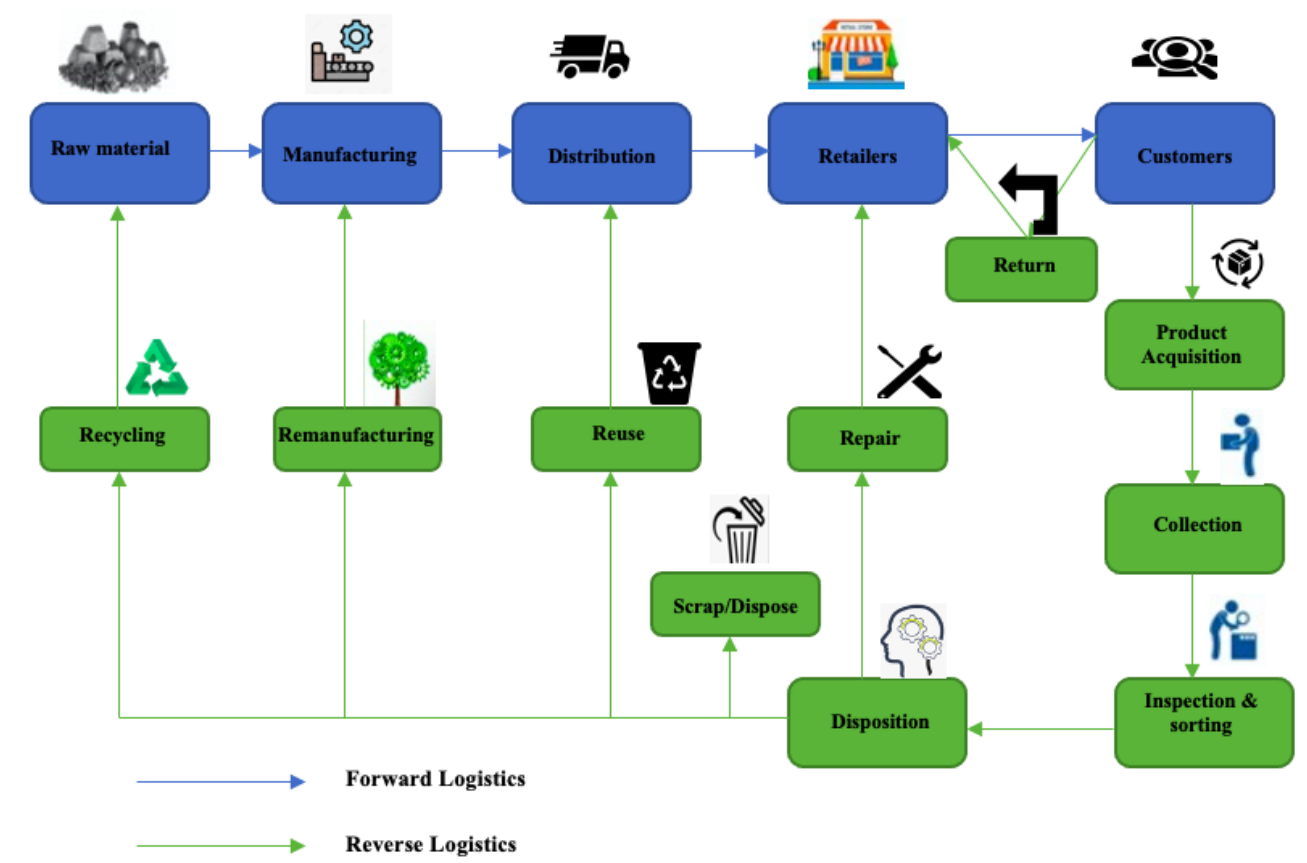

Fig. 3. The basic concept of reverse logistics practices (Updated from Alkahtani et al., 2021)

\section{The Impact of Reverse Logistics on Sustainability Performance The Impact of Reverse Logistics on Economic Performance}

Reverse logistics boost the improvement of a company with profits and strategic benefits. Firms with products subjected to renewal can save equal to $60 \%$ of the new product's total estimated cost (Janusz et al., 2014). The review of alternative reverse logistics disposition options and economic performance is shown in Table 2 (updated from Banihashemi et al., 2019). A literature review found that recycling and reuse are more significant than disposal activities (O'Connell et al., 2013; Vahabzadeh et al., 2015; Khor et al., 2016; Ahmed et al., 2016; Wanjiku and Mwangangi, 2019), as shown in Table 8. For example, reuse and recycle are correlated with the economic significance of decreasing costs of input materials and managing value-adding activities (O'Connell et al., 2013; Zanghelini et al., 2014; Nußholz and Whalen, 2019).

Similarly, recycling and reuse play a significant role in cost reduction and higher market share (Ahmed et al., 2016; Jindal and Sangwan, 2016; Wanjiku and Mwangangi, 2019). Additionally, the economic elements focus on regaining value from the products that are returned, including salvaging integrated circuit boards from electrical products or obtaining valued components from the product via recycling and reuse processes (Vahabzadeh et al., 2015; Ahmed et al., 2016; Khor et al., 2016). Nevertheless, Jindal and Sangwan (2016) discussed that repair is the best recovery process followed by remanufacturing and recycling in profit and energy consumption. The recovery of products for repair through proper disposition is a good advantage for companies (Agrawal et al., 2016). 
Table 2. The review on different disposition reverse logistics and economic performance options

\begin{tabular}{lllllll}
\hline \multicolumn{7}{l}{ Reverse logistics disposition options } \\
Authors & Reuse & Repair & Remanufacture & Recycle & Disposal \\
\hline Vahabzadeh et al (2015) & $\mathrm{V}$ & $\mathrm{V}$ & $\mathrm{V}$ & $\mathrm{V}$ & $\mathrm{V}$ \\
Khor et al (2016) & $\mathrm{V}$ & $\mathrm{V}$ & $\mathrm{V}$ & $\mathrm{V}$ & $\mathrm{V}$ \\
Jindal and Sangwan (2016) & $\mathrm{V}$ & $\mathrm{V}$ & $\mathrm{V}$ & $\mathrm{V}$ & \\
Agrawal et al (2016) & $\mathrm{V}$ & $\mathrm{V}$ & $\mathrm{V}$ & $\mathrm{V}$ & $\mathrm{V}$ \\
Ahmed et al (2016) & $\mathrm{V}$ & $\mathrm{V}$ & $\mathrm{V}$ & $\mathrm{V}$ & \\
Oliveira and Magrini (2017) & & & & $\mathrm{V}$ & \\
Wibowo et al (2014) & & & & & \\
Sabharwal and Garg (2013) & & & $\mathrm{V}$ & & \\
Yalabik et al (2014) & & & $\mathrm{V}$ & & \\
Zanghelini et al (2014) & & & & & \\
O'Connell et al (2013) & $\mathrm{V}$ & & & $\mathrm{V}$ \\
Bahrami and Jafari (2019) & & & & $\mathrm{V}$ \\
Wanjiku and Mwangangi (2019) & $\mathrm{V}$ & & & \\
Nußholz and Whalen (2019) & $\mathrm{V}$ & & & \\
Oliveira Neto and Correia (2019) & & & &
\end{tabular}

The Impact of Reverse Logistics on Environmental Performance

Reverse logistics stimulate alternative resource usage that is cost-effective and environmentally friendly via lengthening the product life cycle (Abdul, 2017). Table 3 (updated from Banihashemi et al., 2019) shows the review on different disposition reverse logistics options and environmental performance. Several researchers examined the environmental performance of reverse logistics implementation and disposition alternatives (Ye et al., 2013; Huang and Yang, 2014; Khor et al., 2016). The studies concluded that implementing reverse logistics could be a factor to improve environmental sustainability performance. As shown in Table 2, recycle is ranked at the top, followed by remanufacturing and finally, reuse. Khor et al (2016) demonstrated that recycling was most profitable for organisations when regulatory pressure is absent.

Similarly, as highlighted by several studies, recycling is the most preferred sustainable management alternative (Wibowo et al., 2014; Agrawal et al., 2016; Ahmed et al., 2016). Recycled materials are beneficial as these materials leave a lower carbon footprint compared to raw materials turned into completed goods in an intensive carbon process (Wibowo et al., 2014; Zanghelini et al., 2014). Furthermore, recycling is a technique utilised to decreases the solid waste stream volume, although the reverse logistics channels used seem to have received minimal attention (Vahabzadeh et al., 2015; Oliverira Neto and Correia, 2019; Wanjiku and Mwangangi, 2019). 
Table 3. The review on different reverse logistics and environmental performance disposition options

\begin{tabular}{llllll}
\hline & \multicolumn{7}{l}{ Reverse logistics disposition options } & \\
Authors & Reuse & Repair & Remanufacture & Recycle & Disposal \\
\hline Vahabzadeh et al (2015) & & $\mathrm{V}$ & $\mathrm{V}$ & $\mathrm{V}$ & $\mathrm{V}$ \\
Khor et al (2016) & & $\mathrm{V}$ & $\mathrm{V}$ & $\mathrm{V}$ & $\mathrm{V}$ \\
Jindal and Sangwan (2016) & & $\mathrm{V}$ & $\mathrm{V}$ & $\mathrm{V}$ & \\
Agrawal et al (2016) & $\mathrm{V}$ & $\mathrm{V}$ & $\mathrm{V}$ & $\mathrm{V}$ & $\mathrm{V}$ \\
Ahmed et al (2016) & $\mathrm{V}$ & $\mathrm{V}$ & $\mathrm{V}$ & $\mathrm{V}$ & \\
Oliveira and Magrini (2017) & & & & $\mathrm{V}$ & $\mathrm{V}$ \\
Wibowo et al (2014) & & & & $\mathrm{V}$ & \\
Sabharwal and Garg (2013) & & & & & \\
Yalabik et al (2014) & & & $\mathrm{V}$ & $\mathrm{V}$ & $\mathrm{V}$ \\
Zanghelini et al (2014) & & $\mathrm{V}$ & & \\
O'Connell et al (2013) & & & & \\
Bahrami and Jafari (2019) & & & & & \\
Wanjiku and Mwangangi (2019) & & & $\mathrm{V}$ & \\
Nußholz and Whalen (2019) & & & & \\
Oliveira Neto and Correia (2019) & & & & & \\
\hline
\end{tabular}

\section{The Impact of Reverse Logistics on Social Performance}

By repairing or restoring broken-down products, reverse logistics can play an important role in customer happiness and loyalty (Banihashemi et al., 2019). Table 4 offers an evaluation of several reverse logistics disposal strategies and social sustainability performance. Hence, recycling is the most vital reverse logistics disposition option for social performance (O'Connell et al., 2013; Jindal and Sangwan, 2016; Agrawal et al., 2016). Recycling plays a significant role in attaining social performance involving customer satisfaction (Wanjiku and Mwangangi, 2019). Nevertheless, reuse can offer employment to the vulnerable and unemployed equal opportunities provided by recycling if conducted via social enterprises (O'Connell et al., 2013; Jindal and Sangwan, 2016; Khor et al., 2016). By examining the reuse and recycling process, the United States Environmental Protection Agency (US EPA) estimated that 10,000 tons of materials create one job at an incinerator, six jobs at landfills, 36 jobs at recycling centres, and 28 to 296 employees in the reuse business. However, reuse may not develop more employment compared to recycling (Sherien et al., 2016). Recycling and reuse characterise a notable feature that provides employment opportunities and social development (Agrawal et al., 2016; Ahmed et al., 2016). 
Table 4. The review on different disposition reverse logistics and social performance options

\begin{tabular}{|c|c|c|c|c|c|}
\hline \multirow[b]{2}{*}{ Authors } & \multicolumn{5}{|c|}{ Reverse logistics disposition options } \\
\hline & Reuse & Repair & Remanufacture & Recycle & Disposal \\
\hline \multicolumn{6}{|l|}{ Vahabzadeh et al (2015) } \\
\hline \multicolumn{6}{|l|}{ Khor et al (2016) } \\
\hline Jindal and Sangwan (2016) & & $\sqrt{ }$ & $\sqrt{ }$ & $\sqrt{ }$ & \\
\hline Agrawal et al (2016) & $\sqrt{ }$ & $\sqrt{ }$ & $\sqrt{ }$ & $\sqrt{ }$ & $\sqrt{ }$ \\
\hline Ahmed et al (2016) & $\sqrt{ }$ & $\sqrt{ }$ & $\mathrm{v}$ & $\sqrt{ }$ & \\
\hline \multicolumn{6}{|l|}{ Oliveira and Magrini (2017) } \\
\hline Wibowo et al (2014) & & & & $\sqrt{ }$ & \\
\hline \multicolumn{6}{|l|}{ Sabharwal and Garg (2013) } \\
\hline \multicolumn{6}{|l|}{ Yalabik et al (2014) } \\
\hline \multicolumn{6}{|l|}{ Zanghelini et al (2014) } \\
\hline O'Connell et al (2013) & $\sqrt{ }$ & & & & \\
\hline \multicolumn{6}{|l|}{ Bahrami and Jafari (2019) } \\
\hline Wanjiku and Mwangangi (2019) & $\sqrt{ }$ & & & $\sqrt{ }$ & \\
\hline \multicolumn{6}{|l|}{ Nußholz and Whalen (2019) } \\
\hline Oliveira Neto and Correia (2019) & & & & & \\
\hline
\end{tabular}

In contrast, research on reverse logistics impacts social performance is limited. The environmental and economic performance of reverse logistics are emphasised more, but the significance of social benefits is overlooked. The economic element of reverse logistic processes identified through numerous cost-benefit analyses has been modelled and debated. Conversely, the social implications of reverse logistics, contributing factors, and critical measures were not comprehensively analysed (Banihashemi et al., 2019).

\section{Conclusions}

This research conducted a thorough analysis of the literature to assess the effectiveness of reverse logistics in terms of three dimensions of sustainability: environmental, economic, and social. Furthermore, most former studies have concentrated on analyzing the influence of reverse logistics on sustainability performance in general without considering the impact of reverse logistics disposal decision-making, which includes recycling, reuse, remanufacture, repair, and disposition. As a result, this study aims to determine which reverse logistics disposal option is best for improving sustainability performance, which could help future research to further investigate the impact of reverse logistics on sustainability performance. Overall, the main findings of this review can support organizations to identify that reverse logistics is an effective tool to achieve sustainability performance, involving economic performance, social performance and environmental performance. It is significant for the top management to implement reverse logistics in the supply chain of the industry. This study also has important implications concerning the disposition for sustainable performance of reverse logistics. It is found that recycling is the most vital disposition decision of reverse logistics for improving customer satisfaction, lowering carbon footprint, reducing cost, and making a higher market share. The results provide guidelines for improved performance of reverse logistics with the aid of disposition decision making. Also, the produced results will be helpful for academicians, industries. The findings suggest that limited studies have looked at reverse logistics' impact on social performance, provided a gap for future research. Finally, practitioners should assess the impact of various reverse logistics disposition alternatives on 
the triple-bottom-line among different industries. Empirical studies on how each disposition option may affect sustainability performance should be conducted.

\section{References}

Afum, E., Agyabeng-Mensah, Y., Sun, Z., Frimpong, B., Kusi, L. Y., and Acquah, I. S. K. (2020). Exploring the link between green manufacturing, operational competitiveness, firm reputation and sustainable performance dimensions: a mediated approach. Journal of Manufacturing Technology Management, 31 (7), 1417-1438.

Agrawal, S., Singh, R. K., \& Murtaza, Q. (2016). Disposition decisions in reverse logistics by using AHP-fuzzy TOPSIS approach. Journal of Modelling in Management, 11(4), 932948.

Agrawal, S., \& Singh, R. K. (2019). Forecasting product returns and reverse logistics performance: structural equation modelling. Management of Environmental Quality: An International Journal, ahead-of-print(ahead-of-print).

Ahi, P., \& Searcy, C. (2015). An analysis of metrics used to measure performance in green and sustainable supply chains. Journal of Cleaner Production, 86, 360-377.

Ahmed, S., Ahmed, S., Shumon, Md. R. H., Quader, M. A., Cho, H. M., \& Mahmud, Md. I. (2016). Prioritizing Strategies for Sustainable End-of-Life Vehicle Management Using Combinatorial Multi-Criteria Decision-Making Method. International Journal of Fuzzy Systems, 18(3), 448-462.

Alkahtani, M., Ziout, A., Salah, B., Alatefi, M., Abd Elgawad, A. E. E., Badwelan, A., \& Syarif, U. (2021). An Insight into Reverse logistics with a Focus on Collection Systems. Sustainability, 13(2), 548.

Anne, M., Nicholas, L., Ithinji, G. K., \& Bula, H. O. (2016). Reverse logistics practices and their effect on competitiveness of food manufacturing firms in Kenya. International Journal of Economics, Finance and Management Sciences 3 (6): 678-684.

Bahrami, B., \& Jafari, P. (2020). Paper recycling, directions to sustainable landscape. International Journal of Environmental Science and Technology, 17(1), 371-382.

Bai, C., Sarkis, J., Wei, X., \& Koh, L. (2012). Evaluating ecological sustainable performance measures for supply chain management. Supply Chain Management: An International Journal, 17(1), 78-92.

Beske, P., Land, A., Seuring, S. (2014). Sustainable supply chain management practices and dynamic capabilities in the food industry: a critical analysis of the literature. Int. J. Prod. Econ. 152

Büyüközkan, G., \& Çifçi, G. (2013). An integrated QFD framework with multiple formatted and incomplete preferences: A sustainable supply chain application. Applied Soft Computing, 13(9), 3931-3941.

Cao, M., \& Zhang, Q. (2011). Supply chain collaboration: Impact on collaborative advantage and firm performance. Journal of Operations Management, 29(3), 163-180.

Chardine-Baumann, E., \& Botta-Genoulaz, V. (2014). A framework for sustainable performance assessment of supply chain management practices. Computers \& Industrial Engineering, 76, 138-147.

Chopra, S., \& Meindl, P. (2016). Supply chain management: Strategy, planning and operation. Boston: Pearson.

Delai, I., Takahashi, S., 2011. Sustainability measurement system: a reference model proposal. Soc. Responsib. J. 7, 438-471. 
Digalwar, A. K., Dambhare, S., \& Saraswat, S. (2020). Social sustainability assessment framework for indian manufacturing industry. Materials Today: Proceedings.

Eshikhati M. A. (2014). Relationship between reverse logistics practices and organizational performance of manufacturing firms in Kenya (Unpublished MBA project). University of Nairobi, Kenya.

Fahimnia, B., Sarkis, J., and Davarzani, H. (2015). Green supply chain management: a review and bibliometric analysis. International Journal of Production Economics, 162(1), 101114.

Faisal, M. N. (2012). Sustainability metrics for a supply chain: The case of small and medium enterprises. International Journal of Services and Operations Management, 13(3), 392.

Gopal, P. R. C., \& Thakkar, J. (2015). Development of composite sustainable supply chain performance index for the automobile industry. International Journal of Sustainable Engineering, 8(6), 366-385.

Haji Vahabzadeh, A., Asiaei, A., \& Zailani, S. (2015). Green decision-making model in reverse logistics using FUZZY-VIKOR method. Resources, Conservation and Recycling, 103, 125138.

Hassini, E., Surti, C., \& Searcy, C. (2012). A literature review and a case study of sustainable supply chains with a focus on metrics. International Journal of Production Economics, 140(1), 69-82.

Hazen, B. T., Boone, C. A., Wang, Y., Khor, K. S. (2017). Perceived quality of remanufactured products: construct and measure development. J. Clean. Prod. 142, 716-726.

Jindal, A., \& Sangwan, K. S. (2016). A fuzzy-based decision support framework for product recovery process selection in reverse logistics. 27.

Kabir, M. I. (2013). Reverse logistics in pharmaceutical industry. International journal of supply chain management, 2(1), 96-100.

Kang, D. (2015). Environmental evaluation of non-alcoholic single-serve PET beverage bottles in the state of California using life cycle assessment and system dynamics. Michigan State University.

Kasman, A., Duman, Y. S. (2015). CO2 emissions, economic growth, energy consumption, trade and urbanization in new EU member and candidate countries: a panel data analysis. Econ. Modell. 44, 97-103.

Khan, S. A. R., Zhang, Y., Kumar, A., Zavadskas, E. K., Streimikiene, D. (2019). Measuring the Impact of Renewable Energy, Public Health Expenditure, Logistics and Environmental Performance on Sustainable Economic Growth. Sustainable Development.

Khor, K. S., Udin, Z. M., Ramayah, T., \& Hazen, B. T. (2016). Reverse logistics in Malaysia: The Contingent role of institutional pressure. International Journal of Production Economics, 175, 96-108.

Kühn, S., 2019. Global employment and social trends. World Employment and Social Outlook 2019(1), 5- 24.

Li, Y., Zhao, X., Shi, D., \& Li, X. (2014). Governance of Sustainable Supply Chains in the Fast Fashion Industry. European Management Journal, 32(5), 823-836.

Liebetruth, T. (2017). Sustainability in Performance Measurement and Management Systems for Supply Chains. Procedia Engineering, 192, 539-544.

Izadikhah, M., \& Saen, R. F. (2018). Assessing sustainability of supply chains by chanceconstrained two-stage DEA model in the presence of undesirable factors. Computers \& Operations Research, 100, 343-367. 
Mariadoss, B. J., Chi, T., Tansuhaj, P., and Pomirleanu, N. (2016). Influences of firm orientations on sustainable supply chain management. Journal of Business Research, 69(9), 3406-3414.

Marulanda-Grisales, N., \& Figueroa-Duarte, O. D. (2021). Classifying and studying environmental performance of manufacturing organizations evidence from Colombia. Journal of Cleaner Production, 279, 123845.

Mirkouei, A., Haapala, K. R., Sessions, J., and Murthy, G. S. (2017). A mixed biomass-based energy supply chain for enhancing economic and environmental sustainability benefits: a multi-criteria decision-making framework. Applied Energy, 206(11),1088-1101.

Moktadir, M. A., Ali, S. M., Rajesh, R., and Paul, S. K. (2018). Modeling the interrelationships among barriers to sustainable supply chain management in leather industry. Journal of Cleaner Production, 181, 631-651.

Mota, B., Gomes, M. I., Carvalho, A., and Barbosa-Povoa, A. P. (2015). Towards supply chain sustainability: environmental and social design and planning. Journal Cleaner Production,105, 14-27.

Murphy, E. (2012). Key Success Factors for Achieving Green Supply Chain Performance; A study of UK ISO 14001 Certified Manufacturers (PhD thesis, The University of Hull).

Narimissa, O., Kangarani-Farahani, A., \& Molla-Alizadeh-Zavardehi, S. (2020). Evaluation of sustainable supply chain management performance: Indicators. Sustainable Development, 28(1), 118-131.

Ndung'u, A. K., \&Moronge, M. (2017). Determinants of Adoption of Reverse Logistics in Manufacturing Firms in Nairobi City County, Kenya.The Strategic Journal of Business \& Change Management, 4 (45), 832-846.

Neri, A., Cagno, E., Lepri, M., \& Trianni, A. (2021). A triple bottom line balanced set of key performance indicators to measure the sustainability performance of industrial supply chains. Sustainable Production and Consumption, 26, 648-691.

O'Connell, M. W., Hickey, S. W., \& Fitzpatrick, C. (2013). Evaluating the sustainability potential of a white goods refurbishment program. Sustainability Science, 8(4), 529-541.

Oliveira, M., \& Magrini, A. (2017). Life Cycle Assessment of Lubricant Oil Plastic Containers in Brazil. Sustainability, 9(4), 576.

Neto, O. G. C., \& Correia, J. M. (2019). Environmental and economic advantages of adopting reverse logistics for recycling construction and demolition waste: A case study of Brazilian construction and recycling companies. Waste Management \& Research: The Journal for a Sustainable Circular Economy, 37(2), 176-185.

Reefke, H., \& Trocchi, M. (2013). Balanced scorecard for sustainable supply chains: Design and development guidelines. International Journal of Productivity and Performance Management, 62(8), 805-826.

Sabharwal, S., \& Garg, S. (2013). Determining cost effectiveness index of remanufacturing: A graph theoretic approach. International Journal of Production Economics, 144(2), 521532.

Sangwan, K. S., Bhakar, V., \& Digalwar, A. K. (2019). A sustainability assessment framework for cement industry - a case study. Benchmarking: An International Journal, 26(2), 470497.

Sapukotanage, S., Warnakulasuriya, B. N. F., \& Yapa, S. T. W. S. (2018). Outcomes of Sustainable Practices: A Triple Bottom Line Approach to Evaluating Sustainable Performance of Manufacturing Firms in a Developing Nation in South Asia. International Business Research, 11(12), 89. 
Sopadang, A., Wichaisri, S., \& Banomyong, R. (2017). Sustainable Supply Chain Performance Measurement A Case Study of the Sugar Industry. 13.

Stindt, D. (2017). A generic planning approach for sustainable supply chain managementHow to integrate concepts and methods to address the issues of sustainability? Journal of Cleaner Production, 153, 146-163.

Susanty, A., Puspitasari, N. B., Purwaningsih, R., \& Hazazi, H. (2019). Prioritization an Indicator for Measuring Sustainable Performance in the Food Supply Chain: Case of Beef Supply Chain. 2019 IEEE International Conference on Industrial Engineering and Engineering Management (IEEM), 881-885. Macao, Macao: IEEE.

Tajbakhsh, A., and Hassini, E. (2015), "Performance measurement of sustainable supply chains: a review and research questions", International Journal of Productivity and Performance Management, Vol. 64 No. 6, pp. 744-783.

Tsalis, T. A., Malamateniou, K. E., Koulouriotis, D., \& Nikolaou, I. E. (2020). New challenges for corporate sustainability reporting: United Nations' 2030 Agenda for sustainable development and the sustainable development goals. Corporate Social Responsibility and Environmental Management. doi:10.1002/csr.1910

Varsei, M., Soosay, C., Fahimnia, B., \& Sarkis, J. (2014). Framing sustainability performance of supply chains with multidimensional indicators. Supply Chain Management: An International Journal, 19(3), 242-257.

Verdecho, M.-J., Alarcón-Valero, F., Pérez-Perales, D., Alfaro-Saiz, J.-J., \& RodríguezRodríguez, R. (2021). A methodology to select suppliers to increase sustainability within supply chains. Central European Journal of Operations Research, 29(4), 1231-1251.

Wanjiku, E., \& Mwangangi, D., PATRICK. (2019). INFLUENCE OF PROCUREMENT BEST PRACTICES ON THE PERFORMANCE OF FOOD AND BEVERAGE MANUFACTURING FIRMS IN KENYA. International Journal of Supply Chain and Logistics, 3(1), 26.

Wibowo, S., Deng, H., \& Zhang, X. (2014). Evaluating the performance of e-waste recycling programs using fuzzy multiattribute group decision making model. 2014 9th IEEE Conference on Industrial Electronics and Applications, 1989-1994. Hangzhou, China: IEEE.

WMO, W. M. O. (2019). Global Climate in 2015-2019: Climate change accelerates. https://public.wmo.int/en/media/press-release/global-climate-2015-2019-climatechange-accelerates.

Xu, J., Jiang, X., \& Wu, Z. (2016). A Sustainable Performance Assessment Framework for Plastic Film Supply Chain Management from a Chinese Perspective. Sustainability, 8(10), 1042.

Yakovleva, N., Sarkis, J., \& Sloan, T. (2012). Sustainable benchmarking of supply chains: The case of the food industry. International Journal of Production Research, 50(5), 12971317.

Yalabik, B., Chhajed, D., \& Petruzzi, N. C. (2014). Product and sales contract design in remanufacturing. International Journal of Production Economics, 154, 299-312.

Zailani, S., Jeyaraman, K., Vengadasan, G., \& Premkumar, R. (2012). Sustainable supply chain management (SSCM) in Malaysia: A survey. International Journal of Production Economics, 140(1), 330-340.

Zanghelini, G. M., Cherubini, E., Orsi, P., \& Soares, S. R. (2014). Waste management Life Cycle Assessment: The case of a reciprocating air compressor in Brazil. Journal of Cleaner Production, 70, 164-174.

Zhang, J. H., Chen, M. (2015). Assessing the impact of China's vehicle emission standards on diesel engine remanufacturing. J. Clean. Prod. 107, 177-184. 
Zhang, C., Cai, W., Liu, Z., Wei, Y.-M., Guan, D., Li, Z., ... Gong, P. (2020). Five tips for China to realize its co-targets of climate mitigation and Sustainable Development Goals (SDGs). Geography and Sustainability, 1(3), 245-249. 